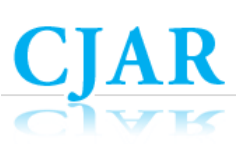

Canadian Journal of Action Research Volume 19, Issue 2, 2018, pages 67-79

\title{
FEMALE STUDENTS TALK ABOUT WOMEN COMPOSERS: TWO MISCONCEPTIONS AND A SELF-LIMITING BELIEF
}

\author{
Anne Bonnycastle \\ Crofton House School, Vancouver, BC
}

\begin{abstract}
This paper describes an action research project that investigated female high school orchestral students' reflections after they had spent a term playing an all-female composed repertoire set. Analysis of conversational interviews showed that participants commonly held two misconceptions: that few women composed music in the past and that there is no gender gap in contemporary music composition. At the same time, participants attributed their intention to not pursue music composition as a career to their belief that they lacked the innate talent and creativity required to become a successful composer. Simply adding women composers to the repertoire was not sufficient an intervention to change students' attitudes: the need for further educational intervention is discussed.
\end{abstract}

\section{INTRODUCTION}

Reflecting on my own practice as the orchestra director at an independent girls' school, I had noticed that every piece had been written by a male composer. I looked at recommended repertoire lists for youth and high-school orchestras to determine whether this was common practice. In the UK, National Association of Youth Orchestras' (2015) Music for Youth Orchestras recommends 609 pieces: not one was composed by a woman. In America, the Pennsylvania Music Educators' Association Festival Repertoire List (2017) and the West Virginia Orchestra Repertoire List (n.d.) contained a negligible number of women-composed pieces (less than .5\%). Discussion with colleagues also confirmed my 
suspicion that youth and high school orchestras rarely play music composed by women. Given that music learning in school orchestral settings is focused on the pieces rehearsed in class (Reynolds, 2002), it concerned me that my female students might be negatively impacted by the absence of music written by women.

The absence of female-composed repertoire in orchestra class might be explained by the facts that orchestral repertoire is chosen extensively from historic western musical traditions, and that in the past, fewer women than men composed for orchestra (Pendle, 2001). However, although social conditions that existed prior to the mid-twentieth century were more conducive to men's endeavours in music composition than women's (Halstead, 1997), a great many women did in fact compose music throughout the history of western music. For example, see Appendix A for a partial list of women orchestral composers by musical era.

Today, women are still under-represented in the field of contemporary music composition (Citron, 2000). Numbers show that the gender gap in contemporary music composition is substantial: in the 2014/15 concert season of 21 major American symphony orchestras, of works performed that were written by living composers, only $14.3 \%$ were composed by women (O'Bannon, 2016). Much of contemporary orchestral music is composed for film scores. In 2016, of the top 250 films produced in Hollywood, only 1\% of the film scores were female-composed (Lauzen, 2017). In 2011, women earned 15.8\% of PhDs in music composition, the lowest percentage across all academic fields, including STEM (National Science Foundation, 2011). When I considered these statistics, the following questions emerged: Why are so few women today engaged in music composition? Given that career direction typically takes shape during adolescence (Hill et al., 2017), could it be that exposing female music students to only male-composed music somehow limits their sense of possibilities for themselves? What would be the effect of adding women-composed music to my students' repertoire set? Would this experience expand my students' sense of possibilities for themselves as composers?

These questions formed the impetus for this action research project, outlined as follows: At the beginning of the 2018 spring term (January to March), I assigned my orchestra class three pieces from varying historical eras: Fanny Mendelssohn's Overture in C+ (written in 1826), a trio-sonata by Anne-Amelie de Brunswick (1756), and the Prelude to the Suffolk Suite, written by Doreen Carwithen (1945). Prior to assigning the music, I gave my students a short survey to establish baseline data. After rehearsing the women-composed repertoire set for three months and performing it at the spring concert, I interviewed my students, described in detail below. I was interested to find out what my students' attitudes towards music composition might be, especially after having spent a term playing women-composed music.

\section{LITERATURE REVIEW}

This project is informed by research on the intersections of feminism and music education, possible selves and gender gaps in other fields. 
Lamb, Dolloff and Howe (2002) explained that the appearance of feminist issues in music education has been recent (p. 655), and has not yet considered the creation of non-sexist music education curricula. Instead, music education researchers have concerned themselves with identifying sex stereotyping of school musical activities such as instrument choices (e.g., Griswold \& Chroback, 1981) and with exposing gender bias in music teaching and learning (e.g., Green, 1993). One exception is Cousens' (1997) dissertation, which dealt with gendered repertoire choices in choral classrooms.

Cousens (1997) suggested that the dearth of present-day female choral composers might be attributed to the failure of schools to use female-composed music in their choral classes. Cousens interviewed students in high school choral classrooms and their teachers, to determine whether "the gender of a composer (of class repertoire) may motivate female students to consider a career in music composition" (p. 3). This is very close (but not identical to) my investigation. Cousens found responses to be mixed, and was unable to form a definitive conclusion that the gender of the composer had any impact on students' career choices. However, in her conclusion, Cousens (1997) wrote that: "If teachers omit the works by women, consciously or unconsciously, then students may misinterpret these actions as views that women are incapable of writing quality music, worthy of study" (p. 154). Cousens made this observation 20 years ago, and yet my literature search has not revealed any further investigation of this topic.

Possible selves. The possible selves framework, developed by Markus and Nurius (1986), is a future-oriented approach to self-concept. According to this theory, an individual's self-view includes not only their perception of their current capacities, weaknesses and characteristics, but also includes beliefs about possibilities for themselves in the future. Possible selves pertain to career choice. For example, Hill et al., (2017) showed that among middle school students, science possible selves (the belief that "if I wanted to become a scientist, I would be able to," p. 6) were associated with a desire to pursue a career in science. In my study, the concept of possible selves is useful in understanding how students' sense of possibility for themselves impacts whether they decide to pursue, or not pursue, a career in music composition.

Gender gaps in other fields. There is a significant amount of research on the gender gap in STEM careers. For example, Shin, Levy and London (2016) found a positive effect of role models on STEM career choice; similarly, Lips (2017) demonstrated a positive correlation of possible selves with STEM career choice. A particularly salient study by Leslie, Cimpian, Meyer, and Freeland (2015) examined gender representation in academia across 30 fields within both the humanities and STEM. The authors explained that although current discourse focuses on the fact that women are underrepresented in STEM fields, there is less attention paid to the fact that female representation within STEM fields varies significantly, and that varying degrees of gender imbalance also exist in the social sciences and humanities. The authors' data supported the field-specific ability beliefs hypothesis: Women are under-represented in fields that are perceived to require brilliance (such as philosophy, math, physics and music composition) and better-represented in fields that are perceived to require hard work and persistence (such as psychology, neuroscience and molecular 
biology). In other words, women may be self-selecting out of fields that are perceived to require "brilliance," because they have internalized the idea that men are brilliant and they are not. Leslie et al. (2015) extended my research questions: are young women choosing not to pursue music composition because they have only ever had exposure to malecomposed music, and thus have developed a limited sense of possible self, and/or because they believe that they do not have the "brilliance" supposedly required to succeed in music composition?

\section{Problem ANd Aim of THE STUdy}

In performance-based large ensemble music programs, the repertoire (similar to textbook use in other subjects), chosen by the music teacher, forms the basis of students' musical and learning experiences. When every piece of music in the high school orchestra repertoire is male-composed, this may send the message that only male composers matter. This could affect girls in a variety of ways. One effect might be to limit girls' possible selves as a music composer. Another might be to suggest that only men have the brilliance required to succeed in this career. My study was designed to explore these issues, by adding female-composed music to the classroom repertoire of my high school orchestra, and uncovering students' thoughts and perceptions about women-as-composers, and about themselves as composers.

\section{MethodologY \\ Participants}

Participants involved in this study were students the high school orchestra that I teach, within an independent high school for girls, located in a large city on the West coast of Canada, with an enrollment of approximately 500 students for the 2017-18 academic year. The orchestra at this school consists of 48 female students from grades 8 to 12 . This ensemble rehearses two mornings per week, from 7:15am to 8:15am. Students receive course credit for the work done in this ensemble.

\section{Procedure}

Prior to administering the all-female repertoire set, I gave the students a short survey that included the following questions: What are the names of the first five composers that come to mind? After these first 5, what are the names of all the composers that they can think of? Students were told that filling out the survey was entirely voluntary, responses would remain anonymous, and that survey results were in no way tied to their course evaluation.

From January to April 2018, the orchestra rehearsed the set of women-composed music (described above), and performed the pieces at a local music festival and at their spring concert. In April, I invited all the students in the orchestra to participate in conversational interviews with me "about their thoughts and feelings related to our orchestra repertoire." I clearly communicated that participation in these interviews was voluntary and in no way tied to course assessment. 
Twenty-two students volunteered for the interviews, which were conducted in groups of one, two or three students at a time, according to the participants' preferences. Students were evenly represented across grades 8 to 12 .

Interviews lasted about 45 minutes; I audio-recorded the sessions for subsequent transcription. At the beginning of each session, I communicated the confidentiality measures I had taken (transcriptions would be shared only with them, and excerpts used for any subsequent publication would use pseudonyms), and reminded the students of the purely volunteer nature of their participation.

I created interview questions designed to elicit a flow of perceptions, thoughts, assumptions and descriptions of experiences. During the sessions, I allowed the flow of the conversations to dictate the order of the questions and provocations, which included:

1. Imagine a music composer. Can you tell me what this composer looks like?

2. What do you like about our current repertoire set? What don't you like?

3. Think about the pieces we are playing this term. Do you notice a theme?

4. I have noticed that prior to this term that not one of the pieces we have played was composed by a woman. I have also looked at the repertoire sets for other schools and orchestras - again, none contain women-composed pieces. What are your thoughts about this?

5. Do you think it is important that youth orchestras play music written by female composers? Why does, or why doesn't this matter?

6. Did you know that a study (O'Bannon, 2016) revealed that of the pieces performed by 21 major American orchestras in the 2014/15 concert season, fewer than $2 \%$ were written by women? What are your thoughts about this?

7. This same study looked at all the pieces written by living composers. What do you think was the percentage composed by women?

8. The percentage composed by women was $14.3 \%$. What are your thoughts about that?

9. Another study showed that of the top 250 films produced in Hollywood in 2016, only $1 \%$ of the film music composers were women. What are your thoughts about that?

10. Have you ever thought about becoming a composer, or composing music? Why or why not?

\section{Transcriptions}

I transcribed the interviews, then provided participants with both a copy of the audio recording and my transcription of their session. I invited participants to report any discrepancies: none were reported, apart from some very small details such as verb tense, which I corrected in the transcripts. 


\section{Data Analysis}

Survey. Of the 48 students in the orchestra, 42 returned the survey. I used the survey data simply to gain a sense of students' perceptions prior to assigning the womencomposed music set.

Interviews. Typical for qualitative research, I applied an inductive method to the transcript data in order to allow themes to emerge (Glesne, 2016). I read through the entire set of transcripts, then coded the data, using line-by-line coding. I had a colleague review two of the transcripts to give me feedback on my coding. I assigned preliminary codes, then revisited the transcripts as I worked to group the emerging sub-themes into broader categories. This process was repeated a number of times, until three over-arching themes emerged. I characterized these themes as: two general misconceptions, an appreciation, and one limiting belief.

\section{RESULTS}

\section{Survey results}

In answer to the question "Write down the first five composers you can think of," 15 composers were mentioned, none of them women. In response to the question "In addition to the first five composers you recorded above, write down all the names of composers you can think of," participants named a total of 143 composers. Three were women. These results show that the students' exposure to, and knowledge of female composers prior to the spring term repertoire set, was minimal.

\section{Results of the Data Analysis of the Interviews}

Misconception 1: There were very few, if any women composers in the past. In all of the conversations, participants attempted to explain why orchestras (including our own) typically play almost exclusively male-composed music. The participants' most prevalent explanation was that (a) orchestras play mostly music composed in the past, and (b) in the past, very few, if any, women composed music. While (a) is true, (b) is a misconception (see Appendix 1 for a partial list of the plethora of historic female composers of orchestral music.) Despite having played a women-composed music set for a term, the participants had nevertheless held on to this misconception. For example: "In the past, people would always play pieces by men because there are more pieces by men. The pieces from the past, by women in the past, there weren't that many" (K, grade 8$)$. One participant admitted: "like, off the top of my head, I can't think of any female composers that aren't sisters, or wives of famous male composers" (M, grade 12).

Misconception 2: Male-dominance in music composition is an artifact of the past. Participants invariably explained the dearth of historic women composers as being the result of social conditions "of the time," with the implication that male-dominance in music composition is an artifact of the past. For example: 
In the past, I feel like people were more biased. Because of that, women composers didn't get a chance. So their music would be lost. That was like, in the past. Because of that, women didn't get a chance to shine. Society is now more equal and women get a chance" (H, grade 8$)$.

When I revealed that only $14 \%$ of the music written by living composers performed by the largest 22 American orchestras in the 2014/15 season had been composed by women (O’Bannon, 2016), most of the participants expressed surprise, shock and concern. For example:

It's strange. Like, we never . . . the figures are so surprisingly low, that, like, I would, I never expected to be able to look into music, and be like, $\underline{\text { men }}$... like I don't . . . I don't know. Like with STEM, I, I have that, like, oh, like that females are oppressed in STEM. But in music, I don't see the same thing $(\mathrm{H}$, grade 12).

Appreciation of playing music by women composers. Almost all of the participants were able to identify the theme of the current repertoire set as being women composers, and most of the participants said they appreciated and enjoyed playing a women-composed set. For example, in response to interview question 2: "I really like how they're all female composers - because oftentimes, I play in two other orchestras, sometimes three, normally the composers are all male. 'Cause like, Beethoven, Mozart, yeah, Mendelssohn. So I think it's really interesting" (B, grade 11). While most participants appreciated playing womencomposed music, two participants denied that there was any value in performing music written by women. For example: “I'm always going to prefer, like, (Felix) Mendelssohn's music over his sister's ... I'm always going to like, like Tchaikovsky's. I'm always gonna like prefer that over, say, one of, um, Princess Anne Marie's or like. . I'm gonna prefer their music over it. I will always prefer to play something fun, like, say, Saint Saens" (J, grade 10). The other participant (grade 12) felt that unfortunately students never pay attention to who composed their music, much less to the composer's gender.

Limiting belief. In response to interview question 6, not one of the participants expressed an interest in pursuing music composition themselves, either as an avocation or as a career. In most cases, participants attributed their lack of interest to their low selfefficacy for composing. Some examples: "I don't have the self-discipline" (Y, grade 11), "I don't know if I'm able to, because I'm not a very creative person. I can't write, either (M, grade 12), and "I don't know if I could do it because I don't have the highest level of theory" (I, grade 8). Notably, none of the participants linked the predominance of male composers in their musical world to their own lack of interest in, or self-efficacy for composing.

In two cases, participants did mention that a lack of female role models might have an effect on the low numbers of contemporary female composers: 
It is also just really discouraging why you don't see anyone around you who had gone into music and like, made a good living off it, so maybe that's the reason why men are more encouraged than women to go into music, and go into composing. I mean, like, if the biggest composing guys in this world are men, and they'd be like "oh maybe if I give a shot at this, I can make it." But then, women are like "oh, no other woman has done it before, then I probably won't make it (W, grade 11).

Another participant admitted "Being exposed to female composers - you know there is hope for you as a composer... You show them that there is a possibility for them" (B, grade 11). However, in neither of these examples, nor in any of the data collected, did participants ever suggest that they personally had been affected by the prevalence of male-composed music in their musical upbringing.

\section{DISCUSSION}

Participants in this study had many varied thoughts and opinions about the value of playing women-composed music in orchestra class, about the reasons why women composers are so under-represented in orchestral and film music, and about the prospects for themselves as composers. Although students did enjoy playing a female-composed repertoire set, and many felt that it was a worthwhile endeavor, some felt that an "intervention" of this type would have little effect, generally, on student attitudes and perceptions.

Some of the results from my study are comparable to those of Cousens (1997). Cousens interviewed students in high school choral classrooms and their teachers to determine their perceptions of the value of studying women composed music. Cousens' results did not support the idea that inclusion of female role models in the curriculum might influence girls' career choices. Similarly, my interviewees revealed that their "possible selves" beliefs did not include music composition, even after a term spent playing women-composed music. In other words, the women-composed repertoire set did not have the kind of rolemodel effect on students' possible selves that I had predicted.

In other fields, role model effects have been found. Chormaic, Fee, Tobin and Hennessy (2013) found that strong female role models led to an increase in girls' participation in physics (p. 110). Shin et al. (2016) found that female students' possible selves shifted to include a possible scientist self, after reading biographies of female scientists. My study, on the other hand, did not reveal the kind of data that could lead to a similar conclusion about the value of including female-composed music in the curriculum; however, the "intervention" on which my study was based may have been "too little, too late," or possibly too indirect. Simply playing one female-composed repertoire set in orchestra class cannot undo a lifetime of exposure to a male-dominated field. I would like to suggest that a more targeted approach would be needed to significantly shift attitudes. 
Historically, fewer women composed than men (McCombe, 1999), and this makes femalecomposed music relatively less accessible than male-composed music, especially for music educators. McCombe explained: "social history provides us with the answers as to why there have been so few female composers in the past" (p. 111). However, there are, nevertheless, a large number of historic women composers, and a large body of femalecomposed orchestral repertoire does exist (e.g., Pendle, 2001). That participants of my study remained largely unaware of the existence of historic female composers other than the ones presented in the "intervention" repertoire set, may point to their lack of understanding about the creation of the Western musical cannon. As Citron (2000) pointed out, the Western musical canon is not a straightforward collected of the best quality music in existence. The canon's creation has a complex history of politics, bias, prejudice and happenstance that collectively resulted in a canon that under-represents deserving groups, such as women composers. Without an understanding of these factors, students may well continue to believe, like participant J quoted above, that they will "always prefer" music composed by the "great" male composers with whom they are familiar.

For me, the most significant result from my study was the evidence of low self-efficacy for composing, and the low "possible composer self" admitted by the participants. Not one of the participants felt that they were capable of, or interested in pursuing music composition; the most frequent reason cited was a perception that they lacked the talent, creativity, or some other innate attribute. This echoes the findings of Leslie et al. (2015), who found that among 30 academic disciplines in American universities, fields that were perceived to require innate talent, or "brilliance," for success, were fields that had the lowest proportion of female PhDs. Their data showed that music composition had, along with computer science and physics, the lowest percentage of female PhDs; music composition also had a greater emphasis on brilliance than any field other than mathematics and philosophy. It may be that the female students in my study have internalized an implicit belief that boys are innately more brilliant than girls (essentialism), and that brilliance is required for success in music composition (field-specific belief hypothesis). Further research could examine such beliefs in a larger sample of students.

Shin et al. (2016) showed that role-model exposure was an effective intervention in combatting fixed and essentialist mindsets of female students towards STEM. They also demonstrated that, in their large sample of middle school students, fixed and essentialist mindsets were negatively associated with "possible science self" beliefs, and desire to become a scientist. The role-model exposure intervention had students read biographies of women and ethnic minority scientists. In the biographies, the scientists attributed their success to hard work, rather than to talent. The results of my study suggest that a similar approach might work in music composition.

\section{CONCLUSION AND IMPLICATIONS FOR MY PRACTICE}

This investigation revealed that my female orchestra students, despite having played women-composed music for a nine-week period, maintained two misconceptions: They believed that few women composed music in the past, and that gender imbalance in music 
composition no longer exists. Furthermore, students attributed their own lack of composer possible self to their low self-efficacy for composing. These results suggest to me that:

- my students need to be directly educated about the myriad of women composers in the past and present, and about the flawed process of canon creation;

- my students need to be made aware of the reality of gender imbalance in music composition today;

- my students need to become aware of the effects of essentialist and fixed mindset beliefs on their attitudes and decision-making, and

Beyond continuing to include music composed by women in my future repertoire choices for my student orchestra, my teaching strategies will include:

- Creating an inquiry unit about women composers and canon creation, so that my students will become aware of the multitude of women in the past and the gender bias inherent in the Western music canon;

- Ensuring that students are aware that, like STEM, women are significantly underrepresented in contemporary music composition;

- Assigning a role-model intervention such as the biography approach used by Shin et al. (2016) to combat fixed and essentialist mindsets; and

- Ensuring that I de-emphasize to my students the requirement for raw talent, or "brilliance" for success in music composition.

\section{LIMITATIONS}

The participants in my study represent a specific demographic: they are students in an allgirls' independent school, where tuition is high and academic achievement is emphasized. Their experience and perspectives may not be applicable to students in other contexts. Further research is needed before generalizing the results of my study.

\section{REFERENCES}

Chormaic, S. Fee, S, Tobin, L. and Hennessy, T. (2013). Female role models in physics education in Ireland. Conference proceedings of the Women in Physics conference. doi: $10.1063 / 1.4794244$

Citron, M. (2000). Gender and the Musical Canon. Chicago: University of Illinois Press.

Cousens, M. (1997). The influence of choral works by Canadian women on senior female secondary students in Ontario (Doctoral dissertation). Retrieved from ProQuest Dissertations and Theses. (MQ29153).

Fowler, J. (2005). The Proms 2005 - women composers thin on the ground again. Retrieved from http://www.womeninmusic.org.uk/proms05.htm 
Glesne, C. (2016). Becoming qualitative researchers: An Introduction (5 ${ }^{\text {th }}$ ed.). Boston: Pearson.

Green, L. (1993). Music, gender, and education: A report on some exploratory research. British Journal of Music Education, 10(3), 219-253. doi:10.1017/S02651700001789

Griswold, P. A., \& Chroback, D. A. (1981). Sex-role associations of music instruments and occupations by gender and major. Journal of research in Music Education, 29(1), 5762.

Hill, P., McQuillan, J., Talbert, E., Spiegel, A., Gauthier, G., Diamond, J. (2017). Science possible selves and the desire to be a scientist: Mindsets, gender bias, and confidence during early adolescence. Social Sciences, 6(55). doi:10.3390/socsci6020055

Lamb, R., Dolloff, L., \& Howe, S. (2002). Feminism, feminist research, and gender research in music education: A selective review. In R. Colwell, \& C. Richardson, (Eds.), The New Handbook of Research on Music Teaching and Learning. Oxford: Oxford University Press.

Lauzen, M. (2017). The Celluloid Ceiling: Behind-the-Scenes Employment of Women on the top 100, 250, and 500 films of 2016. Retrieved from https:// www.womeninfilm.ca/ Library/2018 Docs/2017 Celluloid Ceiling Report.pdf

Leslie, S., Cimpian, A., Meyer, M., \& Freeland, E. (2015). Expectations of brilliance underlie gender distributions across academic disciplines. Science, 347(6219), 262-65.

Lips, H. M. (2007). Gender and possible selves. In M. Rossiter (Ed.), Possible selves and adult learning: Perspectives and potential (pp. 51-59). San Francisco: Jossey Bass.

Markus, H., \& Nurius, P. (1986). Possible selves. American Psychologist, 41(9), 954-969. doi:0003-066/86/\$00.75

National Association of Youth Orchestras (UK). (2015). Music for Youth Orchestras Selected in conjunction with National Association of Youth Orchestras (UK). Retrieved from http://www.boosey.com/downloads/Youthorch2007.pdf

National Science Foundation (NSF). (2011). Survey of earned Doctorates. Available at http://www.nsf.gov/statistics/srvydoctorates/

O'Bannon, R. (2016). By the numbers: Female composers. Retrieved from https://www.bsomusic.org/stories/by-the-numbers-female-composers/

Pendle, K. (2001). Women and music: A history. Bloomington: Indiana University Press. 
Pennsylvania Music Educator's Association Festival Repertoire List (2017). Retrieved from https://www.pmea.net/festivals/repertoire-lists/

Reynolds, R. (2002). Repertoire is the curriculum. Music Educators Journal, 87(1).

Shin, J. E., Levy, S. R., London, B. (2016). Effects of role model exposure on STEM and nonSTEM student engagement. Journal of Applied Social Psychology, (46), 410-427. doi: 10.1111/jasp.12371

West Virginia Orchestra Repertoire List (n.d.). Retrieved from https://wvde.state.wv.us/instruction/documents/RecommendedOrchestraReper toireList.pdf

\section{BIOGRAPHICAL NOTE:}

Anne Bonnycastle is the Music Coordinator at Crofton House School, an independent K-12 school for girls in Vancouver. She is currently completing coursework through Boston University towards a DMA degree. 


\section{Appendix A - Partial List of Female Composers by Era}

In order to illustrate the scope of women's orchestral composition in Western classical music, I have compiled this sampling of composers, by era, whose orchestral music has survived and is available.

\begin{tabular}{|c|c|}
\hline $\begin{array}{c}\text { Baroque } \\
\text { Francesca Caccini (1587-1641). } \\
\text { Chiara Margarita Cozzolani (1602-ca. 1676) } \\
\text { Barbara Strozzi (1619-1677) } \\
\text { Isabella Leonarda }(1620-1704) \\
\text { Rosa Giacinta Badalla (1660-ca, 1750) }\end{array}$ & $\begin{array}{c}\text { Classical } \\
\text { Elizabeth-Claude Jacquet de la Guerre (1665-1729) } \\
\text { Antonia Padoani Bembo (1643-1715) } \\
\text { Maria Margherita Grimani (fl. 1713-1718) } \\
\text { Anna Amalia, Princess of Prussia }(1723-1787) \\
\text { Anna Amalia, Duchess of Saxe-Weimar }(1739-1807) \\
\text { Marianna von Martinez (1744-1812) } \\
\text { Maddalena Lombardini Sirmen }(1745-1885) \\
\text { Maria Theresia von Paradis }(1759-1824)\end{array}$ \\
\hline $\begin{array}{c}\text { Romantic } \\
\text { Louise Farrenc (1804-1875) } \\
\text { Fanny Mendelssohn (Hensel) (1805-1847) } \\
\text { Leopoldine Blahetka (1809-1885) } \\
\text { Clara Schumann (1819-1896) } \\
\text { Alice Mary Smith (1839-1884) } \\
\text { Elfrida Andree (1841-1929) } \\
\text { Augusta Holmes (1847-1903) } \\
\text { Luise Adolpha LeBeau (1850-1927) }\end{array}$ & $\begin{array}{c}\text { Late Romantic } \\
\text { Helen Hopekirk (1856-1945) } \\
\text { Cecile Chaminade (1857-1944) } \\
\text { Ethel Smyth }(1858-1944) \\
\text { Melanie Bonis }(1858-1937) \\
\text { Elisabeth Meyer }(1859-1927) \\
\text { Dora Bright }(1862-1951) \\
\text { Edith Swepstone }(1862-1942) \\
\text { Cornelie van Oosterzee (1863-1943) } \\
\text { Clara Anna Korn (1866-1941) } \\
\text { Henriette van den Boorn Coclet }(1866-1945) \\
\text { Margaret Ruthven Lang }(1867-1972) \\
\text { Amy Beach (1867-1944) } \\
\text { Florence Beatrice Price }(1887-1953)\end{array}$ \\
\hline $\begin{array}{c}\mathbf{2 0}^{\text {th }} \text { Century } \\
\text { Rebecca Clarke (1886-1979) } \\
\text { Nadia Boulanger }(1887-1979) \\
\text { Germaine Tailleferre }(1892-1983) \\
\text { Lili Boulanger }(1893-1918) \\
\text { Elizabeth Lutyens }(1906-1983) \\
\text { Grace Williams }(1906-1977) \\
\text { Jean Coulthard (1908-2000) } \\
\text { Elizabeth Maconchy (1907-1994) } \\
\text { Imogen Holst (1907-1984) } \\
\text { Vitezslava Kapralova (1915-1940) } \\
\text { Doreen Carwithen (1922-2003) }\end{array}$ & $\begin{array}{c}\text { Contemporary } \\
\text { Thea Musgrave (1928- ) } \\
\text { Sofia Gubaidulina (1931- ) } \\
\text { Joan Tower (1938- ) } \\
\text { Ellen Taaffe Zwillich (1939- ) } \\
\text { Rhian Samuel (1944- ) } \\
\text { Nicola LeFanu (1947- ) } \\
\text { Diana Burrell (1948- ) } \\
\text { Eleanor Alberga (1949- ) } \\
\text { Odaline de la Martinez (1949- ) } \\
\text { Libby Larson (1950- ) } \\
\text { Judith Weir (1954- ) } \\
\text { Sally Beamish (1956- ) } \\
\text { Jennifer Higdon (1962- ) } \\
\text { Jocelyn Morlock (1969- ) }\end{array}$ \\
\hline
\end{tabular}

